\title{
Archival tagging of subadult and adult common thresher sharks (Alopias vulpinus) off the coast of southern California
}

\author{
Daniel P. Cartamil • Chugey A. Sepulveda • \\ Nicholas C. Wegner • Scott A. Aalbers • \\ Andres Baquero $\cdot$ Jeffrey B. Graham
}

Received: 10 May 2010/Accepted: 30 December 2010/Published online: 14 January 2011

(C) The Author(s) 2011. This article is published with open access at Springerlink.com

\begin{abstract}
The common thresher shark (Alopias vulpinus) is a secondary target species of the California drift gillnet fishery (CA-DGN) and supports a growing recreational fishery in California waters. This study used archival tags to examine the movement patterns and habitat preferences of common threshers of the size range captured in the CA-DGN ( $>120 \mathrm{~cm}$ fork length). Depth and temperaturelogging archival tags were deployed on 57 subadult and adult common threshers in the Southern California Bight. Tags from five individuals $(8.8 \%)$ were recovered, and 154 days of data were successfully obtained from four of these. By night, shark movements were primarily limited to waters above the thermocline, which ranged in depth from 15 to $20 \mathrm{~m}$. Sharks were significantly deeper by day, and daytime vertical distribution consisted of two distinct modes: a 'shallow mode' (wherein sharks occupied only the upper $20 \mathrm{~m}$ of the water column) and a 'deep mode' (characterized by frequent vertical excursions below the thermocline). This modal switch is interpreted as relating to regional differences in abundance of surface-oriented prey and prey in deeper water. Maximum dive depth was $320 \mathrm{~m}$, greatest dive duration was $712 \mathrm{~min}$, minimum temperature experienced during a dive was $9.1^{\circ} \mathrm{C}$, and dive
\end{abstract}

Communicated by S. Garthe.

D. P. Cartamil $(\varangle) \cdot$ N. C. Wegner · J. B. Graham

Scripps Institution of Oceanography, University of California,

San Diego, CA, USA

e-mail: dcartamil@ucsd.edu

C. A. Sepulveda $\cdot$ S. A. Aalbers

Pfleger Institute of Environmental Research,

315 N. Clementine St., Oceanside, CA, USA

A. Baquero

Fundacion Equilibrio Azul, P.O. Box 17116025, Quito, Ecuador descent rate was significantly greater than ascent rate. Sharks inhabited waters corresponding to a sea surface temperature range of 16 to $21^{\circ} \mathrm{C}$. The nocturnal depth distribution of common threshers has implications for management of drift gillnet deployment depths in the CA-DGN.

\section{Introduction}

The common thresher shark (Alopias vulpinus) is a large pelagic species with a cosmopolitan distribution in subtropical and temperate seas (Compagno 2001). Along the west coast of North America, this species occurs from Baja California, Mexico to British Columbia, Canada (PFMC 2003), and is commercially important throughout this range. In Baja California waters, the common thresher is a target of drift gillnet (Olvera 2009) and artisanal shark fisheries (Cartamil 2009). In U.S. waters, it is an important secondary target species of the California drift gillnet fishery (CA-DGN) for broadbill swordfish (Xiphias gladi$u s)$ and constitutes the largest commercial shark fishery in California waters (CDFG 2009). In addition, the common thresher supports a growing recreational fishery in southern California (Heberer et al. 2010). Analyses of CA-DGN catch patterns suggest that the common thresher overwinters offshore of Baja California and migrates north in the spring (Hanan et al. 1993; Smith and Aseltine-Nielson 2001). The highest concentration of common threshers is thought to occur in the Southern California Bight (SCB), a region extending from Point Conception, California $\left(34^{\circ} \mathrm{N}\right.$ latitude), to Cabo Colonet, Mexico $\left(31^{\circ} \mathrm{N}\right.$ latitude) (Carlucci et al. 1986; Hanan et al. 1993).

Acoustic telemetry studies in the SCB have shown that juvenile common threshers generally utilize shallow waters 
over the continental shelf as a nursery habitat (Cartamil et al. 2010a), while subadult and adult common thresher [i.e., $>120 \mathrm{~cm}$ fork length (FL)] occur in deeper waters offshore of the continental shelf (Cartamil et al. 2010b). Larger sharks made vertical excursions by day to depths of up to $220 \mathrm{~m}$ that were suggestive of foraging behavior, whereas nocturnal depths were generally limited to the upper $20 \mathrm{~m}$ of the water column and were strongly constrained by the depth of the thermocline. However, the logistical constraints of acoustic telemetry limited these studies to less than $75 \mathrm{~h}$, which may not be long enough to encompass the full range of behaviors exhibited by the species.

To obtain longer records of the movement patterns of larger common thresher sharks, a study was carried out using non-transmitting archival tags. These tags can record a range of high-resolution environmental data for periods ranging from days to years. They can be implanted or secured externally and have been used extensively on pelagic fishes (Block et al. 1998; Ishida et al. 2001; West and Stevens 2001; Schaefer and Fuller 2002; Schaefer et al. 2007). Archival tags are limited in that they do not gather the full compliment of ambient data possible through active acoustic telemetry tracking, and the fish must be re-captured in order for the data to be extracted from the tag. However, these limitations are balanced by a substantially longer archived data stream. This paper reports the findings of a study in which archival tags were used to examine the depth, temperature preferences, and movement patterns of common thresher sharks in the SCB. Specific goals were to (1) determine whether behavioral trends identified by acoustic telemetry tracking (Cartamil et al. 2010b) persist over longer time periods, (2) examine variability in common thresher shark movement patterns over several weeks, and (3) quantify the relationship between habitat preference and common thresher shark vulnerability to west coast fisheries. Tagging was restricted to subadult and adult common threshers, which are the size classes most commonly captured in the CA-DGN (PFMC 2003).

\section{Methods}

\section{Tagging}

Tagging was accomplished between the periods March 15-August 10, 2004, and March 10- June 22, 2005. Fiftyseven archival tags were deployed over 62 fishing days, primarily offshore of La Jolla, CA (Fig. 1). Common threshers were captured on rod and reel, trolling live baits [Pacific mackerel (Scomber japonicus) or Pacific sardine (Sardinops sagax)] at depths of 5-20 m. After capture, sharks were allowed to swim on the line for 5-10 $\mathrm{min}$ in

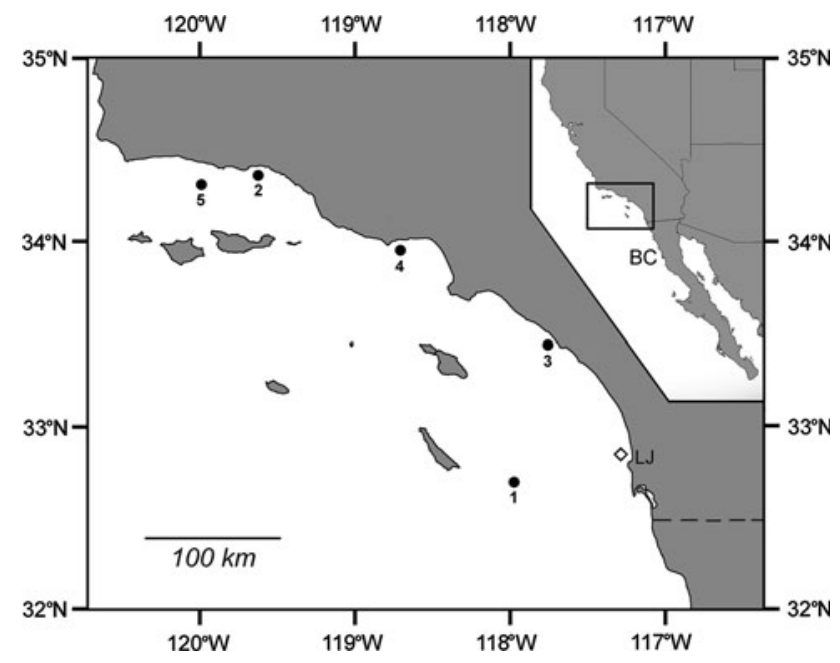

Fig. 1 Tag and recapture locations of five common thresher sharks in the SCB. Open diamond tagging location for all sharks. $\mathrm{LJ}=\mathrm{La}$ Jolla, CA. Black dots recapture locations. Inset shows location of the SCB (in black box) in relation to California and Baja California, Mexico (labeled as BC). Dashed line represents the border between the U.S. and Mexico

order to make them more docile for handling; they were then brought alongside the tagging vessel and restrained in an upright position (i.e., dorsal fin up). A Lotek Inc. (Newfoundland, Canada) model LTD 1,100 archival tag was then mounted on the center of the dorsal fin, with a thin sheet of PVC (underlain by neoprene to minimize fin abrasion) on the side of the fin opposite the tag acting as a backing plate. The tag and backing plate thus 'sandwiched' the dorsal fin and were held together with 1-mm-diameter stainless steel wire that passed through the dorsal fin in two locations approximately $1.5 \mathrm{~cm}$ apart. For each shark, sex, fork length, capture location, handling time, and release condition were recorded prior to release.

Tags were pre-programmed to collect ambient temperature and depth at 1.88-min intervals (except tag 1: $0.94 \mathrm{~min}$ intervals) with a resolution of $\sim 0.2^{\circ} \mathrm{C}$ and $<2.0 \mathrm{~m}$. Tags had dimensions of $8 \mathrm{~mm} \times 16 \mathrm{~mm} \times 27 \mathrm{~mm}$, weighed $5 \mathrm{~g}$ in air ( $2 \mathrm{~g}$ in water), and had a memory storage capacity of approximately $44 \mathrm{~d}$ (except tag 1: $22 \mathrm{~d}$ memory capacity). Acquisition of archived data was dependent upon re-capture of the animal by commercial or recreational fishers, and thus, each tag had reward information and a contact phone number displayed on the exterior. Data were acquired from recovered tags using TagTalk1100 software.

\section{Analyses}

An overview of each shark's vertical movements was obtained by plotting depth against time of day. Vertical distribution was further examined by calculating aggregate time-at-depth distributions in $10-\mathrm{m}$ bins, during both day 
and night periods. The mean thermocline depth for each shark record was estimated by determining the dive-depth range over which the rate of temperature change exceeded $1{ }^{\circ} \mathrm{C}$ per $5 \mathrm{~m}$ of vertical change (Cartamil et al. 2010b). Differences in depth between night and day, between vertical distribution modes (explained in Results), and differences in nocturnal depths during full, new, and intermediate moons (full and new moons refer to the day of each full or new moon and the 2 days preceding and following it) were examined by fitting an ANOVA-type model to the data using weighted least squares. The weights were equal to the inverse of the variance of depth values for each data set tested and are a conservative means of incorporating variability in depth among periods into the analysis. The dependent variable for these models was the average depth during a specified period. Independent variables included a shark effect, to account for animalspecific differences in overall average depth, a vertical distribution mode effect, night/day effect, and lunar period.

To examine diving behavior of common thresher sharks, individual dives were defined as vertical excursions that began in the upper $20 \mathrm{~m}$ of the water column, spanned a minimum depth of $15 \mathrm{~m}$, and were followed by a return to the upper $20 \mathrm{~m}$. These discrete diving periods were quantified in terms of total dive duration, maximum dive depth, and minimum dive temperature. Where dives were followed by a post-dive interval in the warmer waters of the mixed layer, fixed-effect analysis of covariance (ANCOVA) was used to investigate the relationship between post-dive time interval and the above calculated dive parameters (as covariates) using each shark as a fixed effect. Descent and ascent rates were calculated for each dive and compared with a general linear model using each shark as a fixed effect. For all statistical tests, results were considered significant at the $p<0.05$ level.

Shark thermal preferences were determined by pooling temperature data in $1{ }^{\circ} \mathrm{C}$ bins and calculating the percentage of time spent at each bin during day and night periods. The sea surface temperature (SST) range experienced by sharks was estimated using tag temperature data collected at a depth of $<2 \mathrm{~m}$.

\section{Results}

Fifty-seven common thresher sharks were captured and released with archival tags. Of these, five sharks were recaptured in the SCB (Fig. 1) and the tags recovered, for a tag return rate of $8.8 \%$. Time at liberty between tagging and re-capture ranged from 76 to $1,277 \mathrm{~d}$. One of the tags (Shark 5) was damaged and the data could not be extracted, but full data sets were recovered from the remaining four tags; these included two males and two females ranging in size from 129 to $163 \mathrm{~cm}$ FL. Common thresher sharks mature at a size of approximately $160 \mathrm{~cm}$ FL (Smith et al. 2008); thus, the data presented herein are for mature sharks (adults) or those approaching maturity (subadults). Complete shark size, sex, and tagging details are reported in Table 1.

All four sharks exhibited similar post-release behavior, consisting of an immediate deep dive lasting several hours. This was followed by a return to near-surface waters and behavior consistent with the remaining data set (Fig. 2). Because these immediate movements are likely a shortterm response induced by tagging stress (e.g., Klimley et al. 2002; Cartamil et al. 2010b), the first $12 \mathrm{~h}$ of data were not used for analyses.

All sharks spent the majority of the time in the upper $20 \mathrm{~m}$ of the water column. However, a clear diel difference in depth distribution was evident, with sharks occupying significantly deeper waters by day $(8-17 \mathrm{~m})$ than by night (6-12 m) (Fig. 3; Table 2). Furthermore, this general vertical distribution pattern consisted of two distinct modes; throughout the remainder of this paper, these are referred to as 'Shallow' mode and 'Deep' mode. Shallow mode was characterized by a lack of diving activity, whereas Deep mode was characterized by frequent dives during daytime hours to depths that often exceeded $200 \mathrm{~m}$ (Figs. 3, 4). All four sharks exhibited both modes at different times throughout tracks (Figs. 2, 3, 4), and a detailed view of the transition from Shallow to Deep mode for shark 1 is shown in Fig. 3. For analyses, a shark was considered to be in Shallow or Deep mode if it exhibited the characteristic depth distribution for that mode for two or more consecutive days, and dives were excluded prior to testing for

Table 1 Tag and recapture data for five thresher sharks released with archival tags in the SCB

\begin{tabular}{|c|c|c|c|c|c|c|c|c|c|}
\hline \multirow[t]{2}{*}{ Shark ID } & \multirow[t]{2}{*}{ Sex } & \multirow[t]{2}{*}{ FL } & \multirow[t]{2}{*}{ Date } & \multicolumn{3}{|l|}{ Capture } & \multicolumn{3}{|l|}{ Recapture } \\
\hline & & & & N. latitude & W. longitude & Date & N. latitude & W. longitude & D.A.L. \\
\hline 1 & $\mathrm{~F}$ & 163 & 11 June 2004 & 32.89 & 117.27 & 17 Dec 2005 & 32.71 & 118.00 & 554 \\
\hline 2 & M & 129 & 27 April 2004 & 32.90 & 117.27 & 5 July 2007 & 34.38 & 119.53 & 1164 \\
\hline 3 & M & 160 & 31 May 2004 & 32.90 & 117.27 & 15 Nov 2004 & 33.47 & 117.78 & 168 \\
\hline 4 & $\mathrm{~F}$ & 140 & 15 June 2004 & 32.89 & 117.29 & 30 Aug 2004 & 34.03 & 118.63 & 76 \\
\hline 5 & $\mathrm{~F}$ & 135 & 23 June 2004 & 32.89 & 117.29 & 22 Dec 2007 & 34.32 & 119.97 & 1277 \\
\hline
\end{tabular}

$F L$ fork length (at time of tagging), D.A.L. days at liberty 

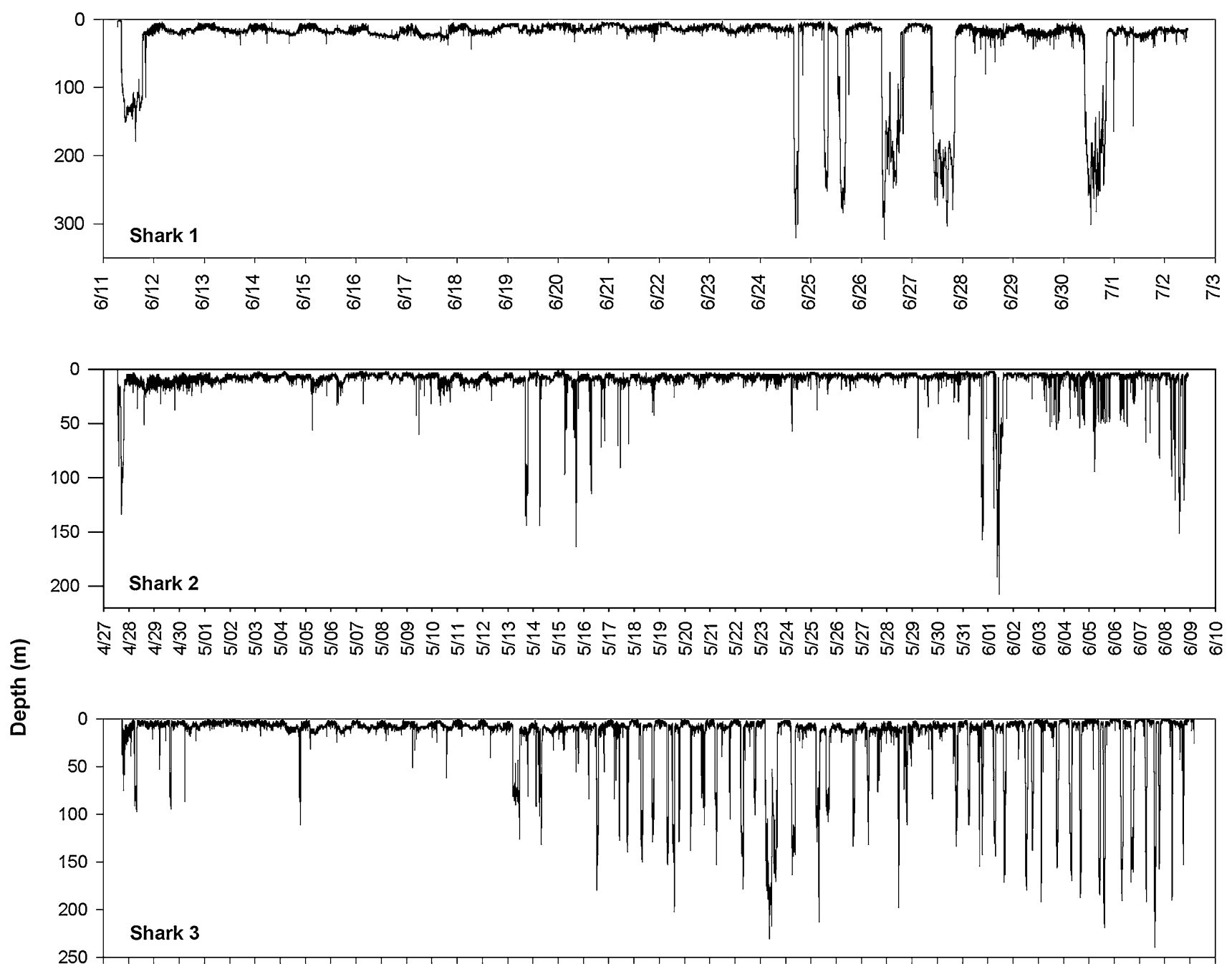

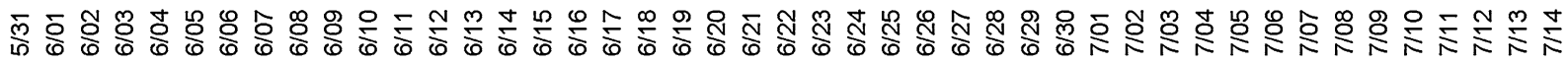

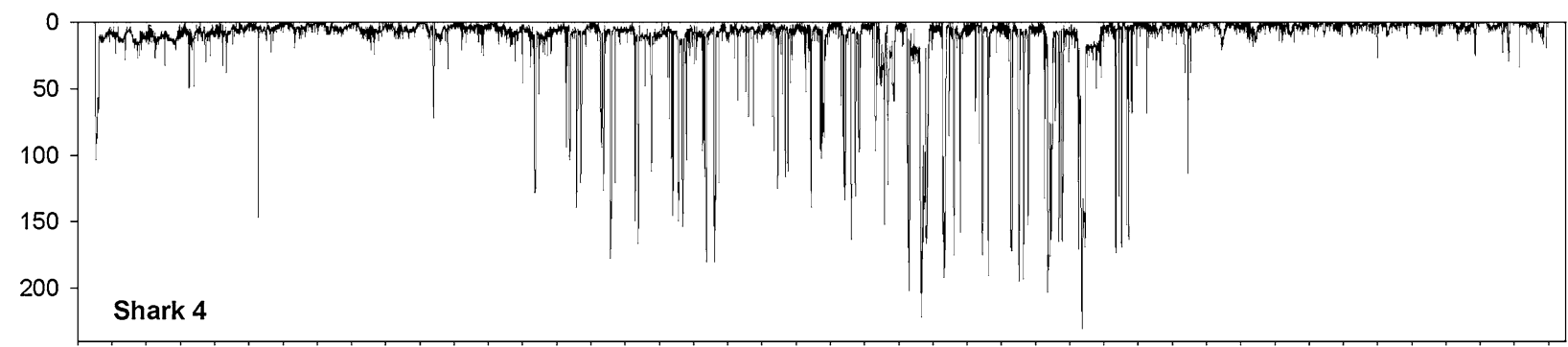

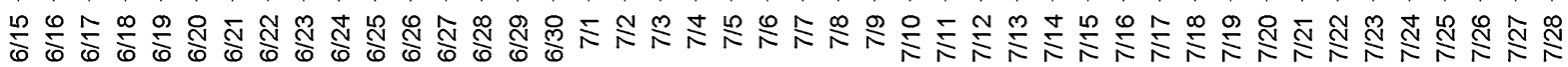

Date (M/D)

Fig. 2 Dive profiles of the four archivally tagged common thresher sharks

differences between modes (dives had a disproportionally large effect upon the mean, and thus skewed an accurate description of the primary depth distribution). During both Deep and Shallow modes, daytime depths were significantly greater than nocturnal depths. For individual sharks, both daytime and nocturnal depths were significantly greater in Deep mode than in Shallow Mode. The mean ( \pm S.D.) depths of each shark in both modes are given in Table 2, as is the estimated thermocline depth, which ranged from approximately 14 to $19 \mathrm{~m}$. Sharks spent the 


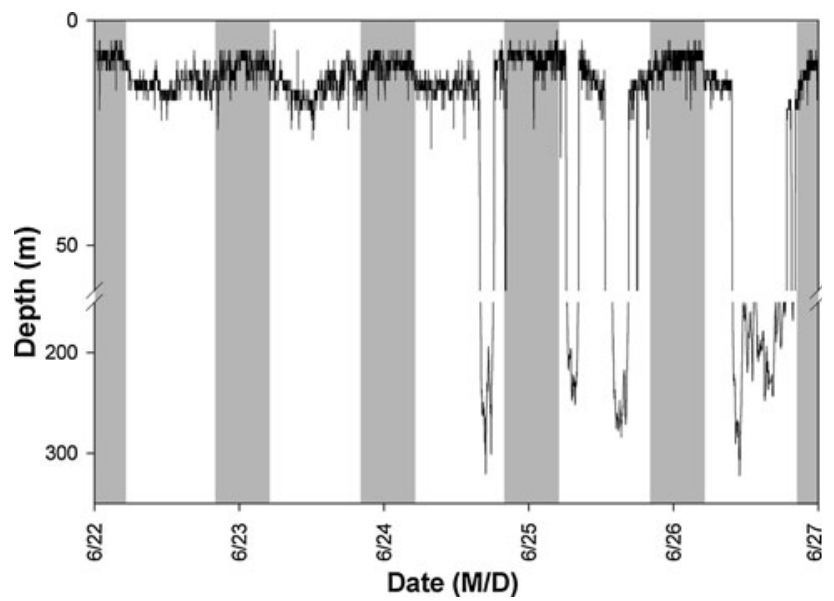

Fig. 3 A representative 5-day section of archival data from Shark 1, showing the abrupt transition from Shallow to Deep mode of vertical distribution. Bars indicate night (gray) and day (white)

majority of their time above the thermocline, regardless of mode.

Analyses were conducted on 372 discrete dives. Dives were usually $<200 \mathrm{~m}$ in depth, but maximum dive depth recorded was $320 \mathrm{~m}$ (Fig. 5). Most dives (57\%) were $<20 \mathrm{~min}$ in duration, but maximum dive duration was 712 min (Fig. 6). Post-dive intervals were not significantly correlated to any of the calculated dive parameters. Rate of descent $\left(21.1 \pm 14.5 \mathrm{~m} \mathrm{~min}^{-1} ; \bar{X} \pm \mathrm{SD}\right)$ was significantly higher than rate of ascent $\left(11.6 \pm 6.5 \mathrm{~m} \mathrm{~min}^{-1}\right)$ (Fig. 7).

Archival tag data show similar temperature ranges, from $21.3^{\circ} \mathrm{C}$ at the surface to a low of $9.1^{\circ} \mathrm{C}$ at maximum depth (Fig. 8). SSTs from June to July 2004 (sharks 1, 3, and 4) ranged from 18.6 to $21.1^{\circ} \mathrm{C}$. Shark 2 , which was tagged in late April 2004, encountered SSTs as low as $15.5^{\circ} \mathrm{C}$. Lunar phase had no effect on nocturnal depth distribution.

\section{Discussion}

Daytime movements

Shallow and Deep modes of behavior relate to the daytime distribution of tagged common thresher sharks. The archival records of each shark show abrupt switches between Shallow and Deep modes that may be related to the vertical distribution and abundance of prey. Small coastal pelagic fishes such as the northern anchovy (Engraulis mordax), Pacific sardine, and Pacific mackerel comprise the majority of common thresher shark diet in the SCB (Preti et al. 2001, 2004) and typically occur in surface waters during daylight hours (Allen and DeMartini 1983). Sharks exhibiting Shallow mode behavior may be foraging near the surface when these prey species are abundant. The switch to a Deep mode of vertical distribution may occur when surface prey are scarce and sharks commence foraging for deeper prey such as Pacific hake (Merluccius productus) (Preti et al. 2001, 2004), which commonly occurs beyond the continental shelf at depths of up to $500 \mathrm{~m}$ (Ressler et al. 2007). Other potential deep-water prey include louvar (Luvarus imperialis), market squid (Loligo opalescens), and rockfishes (Sebastes sp.) (Preti et al. 2001, 2004). Deep and Shallow modes of diving have previously been described for other pelagic fish species such as swordfish (Sepulveda et al. 2010) and yellowfin tuna (Thunnus albacares) (Schaefer et al. 2007).

An alternative explanation for the diving behavior of common thresher sharks is that it provides an efficient mechanism for transportation. Weihs (1973) asserted that negatively buoyant fish might move from place to place with less energy expenditure by adopting a 'swim-glide' mode of locomotion, wherein the shark would be expected to descend slowly and ascend at a faster rate. However, the dive profiles of archivally tagged common threshers reveal the opposite tendency, as has been reported for several pelagic sharks (Carey and Scharold 1990; Nakano et al. 2003; Dewar et al. 2004; Sepulveda et al. 2004). Common thresher shark 'fast-down', 'slow-up' dive profiles may be indicative of prey searching as has been previously postulated for similar species (Carey and Scharold 1990; Nakano et al. 2003).

Nocturnal movements

Nocturnal depth preference appears to be strongly influenced by the depth of the thermocline, and over $90 \%$ of

Table 2 Total number of days of archived data collected for each shark, the number of days each shark spent in shallow and deep mode, and the mean $( \pm \mathrm{SD})$ depths occupied by the shark in each mode during day and night (excluding dives), relative to average thermocline (TC) depth

\begin{tabular}{|c|c|c|c|c|c|c|c|c|}
\hline \multirow[t]{2}{*}{ Shark } & \multicolumn{3}{|l|}{ Days } & \multicolumn{2}{|c|}{ Shallow mode depths (m) } & \multicolumn{2}{|c|}{ Deep mode depths (m) } & \multirow[t]{2}{*}{ TC depth (m) } \\
\hline & Total & Shallow & Deep & Night & Day & Night & Day & \\
\hline 1 & 22 & 16 & 6 & $10.77 \pm 3.54$ & $17.06 \pm 4.33$ & $12.34 \pm 4.16$ & $17.44 \pm 4.55$ & $18.8 \pm 1.6$ \\
\hline 2 & 44 & 19 & 25 & $6.46 \pm 2.75$ & $8.49 \pm 3.18$ & $7.05 \pm 1.94$ & $9.60 \pm 2.91$ & $13.8 \pm 2.1$ \\
\hline 3 & 44 & 13 & 31 & $6.94 \pm 2.33$ & $9.85 \pm 2.96$ & $7.15 \pm 3.24$ & $10.03 \pm 3.41$ & $15.7 \pm 1.1$ \\
\hline 4 & 44 & 20 & 24 & $5.98 \pm 3.07$ & $8.19 \pm 3.85$ & $8.09 \pm 3.16$ & $10.34 \pm 4.94$ & $15.4 \pm 1.6$ \\
\hline
\end{tabular}


Fig. 4 Depth distribution for each shark during Shallow (left) and Deep modes (right). Color scale denotes the percentage of time at given depths. Dotted white line shows time of sunrise and sunset
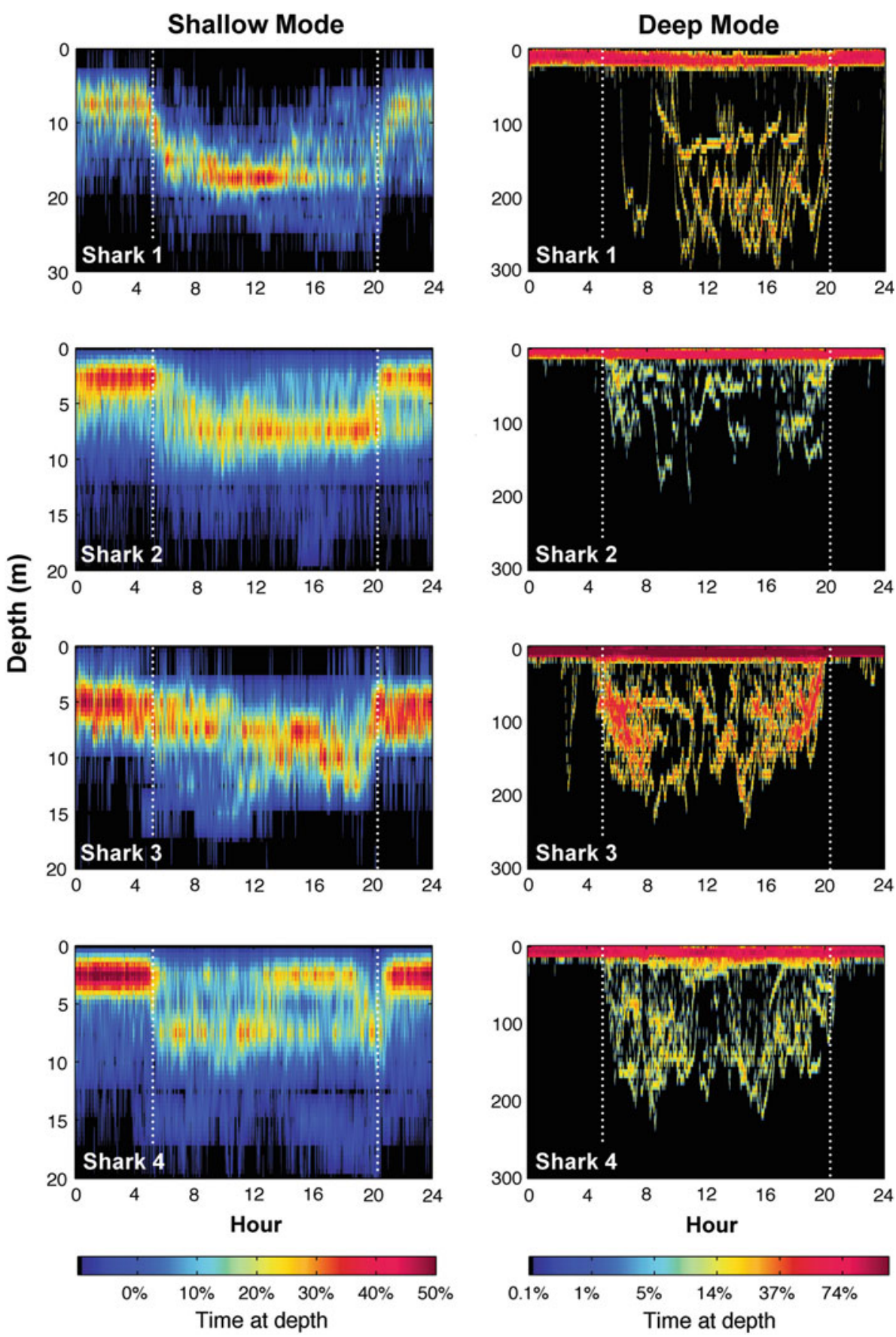

nocturnal depth readings were located above estimated thermocline depths. Why did common thresher sharks inhabit such shallow waters by night? One possibility is that they are foraging in the mixed layer. However, several factors argue against this. First, northern anchovy and Pacific sardine schools often disperse at night (Allen and DeMartini 1983), which could make predation more difficult. Secondly, the common thresher utilizes a unique mode of predation, wherein prey is struck with the elongate upper lobe of the caudal fin prior to capture (Gubanov
1972; Aalbers et al. 2010), and this behavior may require light levels higher than those available at night. A nocturnal preference for the warmer mixed layer after daytime predatory activity could be a form of post-feeding thermoregulation; common threshers might benefit from warmer temperatures by increased digestive rate and assimilation efficiency (Wurtsbaugh and Neverman 1988). However, feeding periodicity has not been investigated for this species, and the possibility of nocturnal feeding cannot be ruled out. 
Fig. 5 Swimming depth $(10-\mathrm{m}$ bins) histograms for archivally tagged common thresher sharks during night and day

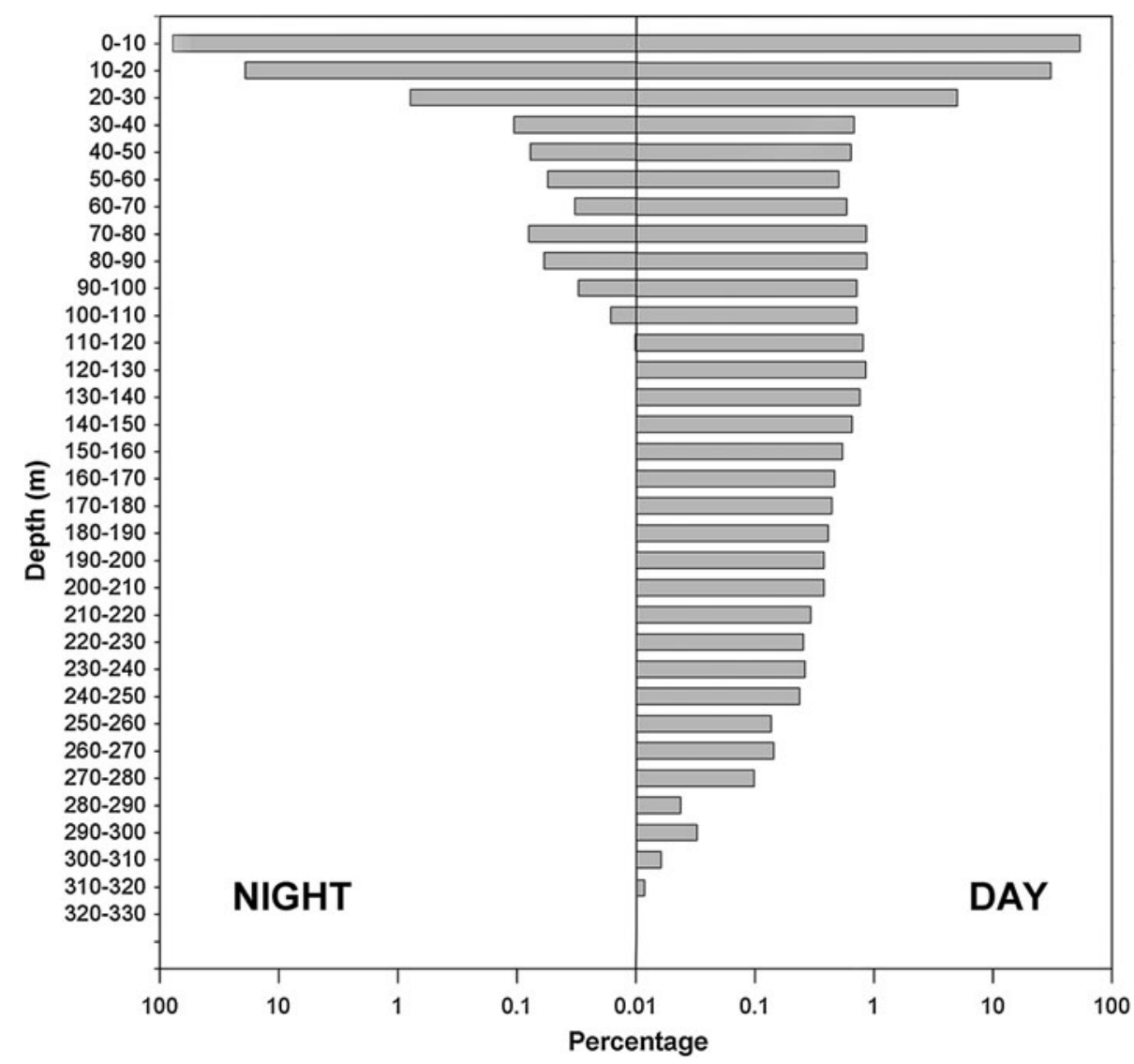

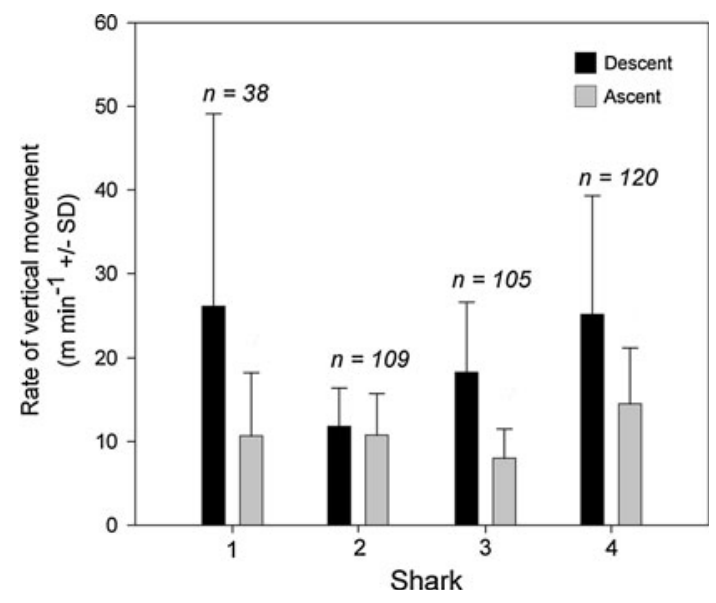

Fig. 6 Dive duration histograms for archivally tagged common sharks, showing percentage of time spent in each time bin

Unlike other shark species that dive deep during full moons (Carey and Scharold 1990; West and Stevens 2001; Weng et al. 2007), lunar phase had no effect upon the nocturnal depth of common threshers. However, typical southern California spring weather conditions [characterized by a dense and persistent marine cloud layer caused by the intrusion of warm Pacific air moving over colder waters (LaDochy and Brown 2003)] prevailed during May and

Fig. 7 Mean descent and ascent rates for archivally tagged common thresher sharks. Numbers indicate the total number of dives used for rate calculations

June 2004 when most archival data were collected, and may have decreased lunar illumination sufficiently to prevent a light response. Additionally, if common thresher shark foraging is predominantly a daytime activity, nocturnal depth would not be expected to be influenced by changes in prey vertical distribution corresponding to lunar illumination. 


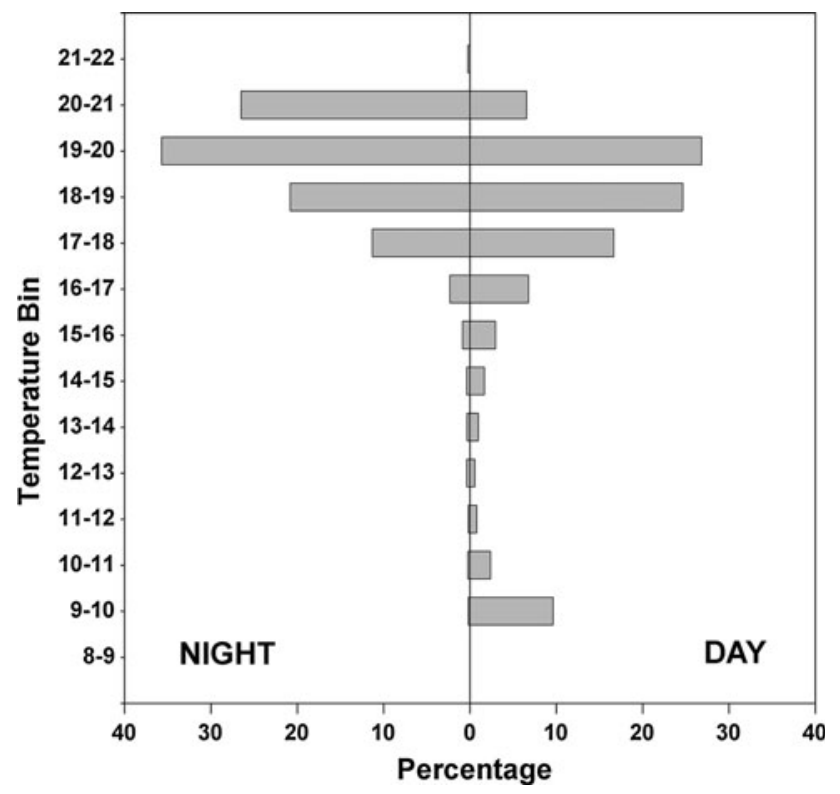

Fig. 8 Temperature-occurence $\left(1^{\circ} \mathrm{C}\right.$ bins) histograms for archivally tagged common thresher sharks during night and day

\section{Physiology}

Temperatures at the maximum depths attained by common threshers were up to $12^{\circ} \mathrm{C}$ lower than those at the surface. Prolonged exposure to low temperatures during dives imposes various physiological stresses such as a reduction in cardiovascular function (Blank et al. 2004), power output (Altringham and Block 1997), and temporal resolution of vision (Fritsches et al. 2005). However, the common thresher possesses vascular retia that enable it to elevate red muscle temperature above that of ambient water (Bone and Chubb 1983; Bernal and Sepulveda 2005; Sepulveda et al. 2005), and this capability for regional endothermy may allow the common thresher to withstand cooler temperatures for longer durations than pelagic ectotherms of similar mass. For example, the blue shark (Carey and Scharold 1990), scalloped hammerhead shark (Sphyrna lewini) (Klimley 1993), and ocean sunfish (Cartamil and Lowe 2004) dive through temperature gradients as severe as those encountered by the common thresher, but do not usually remain at maximum depth for more than a few minutes; this is reflected in their 'yo-yo' dive patterns. By contrast, almost $40 \%$ of common thresher dives were longer than $30 \mathrm{~min}$ and $11 \%$ were longer than $100 \mathrm{~min}$, with a maximum dive duration of $712 \mathrm{~min}$.

Common thresher sharks often made several dives throughout the day that were punctuated by short surface intervals, which could facilitate recovery from reduced body temperature incurred during dives (Carey and Robison 1981; Carey and Scharold 1990; Cartamil and Lowe
2004; Dewar et al. 2004). No relationship was found between the depth, temperature or duration of dives and subsequent surface intervals for archivally tagged common threshers. Therefore, while these intervals may be physiologically beneficial, their duration does not appear to be constrained by thermal stress incurred during the preceding dive.

\section{Fisheries implications}

Most of the U.S. commercial and recreational catch of the common thresher shark occurs in the SCB (Hanan et al. 1993; PFMC 2003). This importance of this region is further illustrated by the recapture of all tagged common threshers in the SCB, with three sharks caught by the CADGN, and two by recreational fishers. A tag return rate of $8.8 \%$ is considered fairly high for pelagic sharks (Kohler and Turner 2001) and reflects the fishing pressure on this species. Nevertheless, this rate likely underestimates the actual capture of tagged common threshers due to transboundary movements into Mexican waters (Baquero 2006), where tags from sharks captured in Mexican fisheries (Cartamil 2009; Olvera 2009) are often discarded at sea (D. Cartamil, personal observation). The possibility also exists that some tags were lost due to shedding, although the maximum time-at-liberty of $1,277 \mathrm{~d}$ suggests that the tag attachment was generally secure.

Off southern California, recreational fishing for common threshers has increased over the past decade and now is believed to significantly contribute to the total annual harvest of this species off the U.S. west coast. This sport fishery targets thresher sharks by trolling baited lures at depths of up to $20 \mathrm{~m}$ during the day (Heberer et al. 2010). Based on the daytime depth distribution within the waters of the upper mixed layer observed in this study, it is apparent that thresher sharks are vulnerable to recreational fishing gear throughout a majority of the daylight hours.

Within U.S. waters, the primary fishery impacting the common thresher is the CA-DGN. Drift gillnets are set at dusk and retrieved before dawn, and therefore, it is the nocturnal depth distribution of the common thresher shark that determines its susceptibility to CA-DGN gear. In the present study, only $23 \%$ of nocturnal depth readings were located below six fathoms, suggesting that catch rates of the common thresher could be reduced by increasing the minimum net depth (i.e., setting at depths of $>6$ fathoms) or increased by setting nets shallower than 6 fathoms, depending upon fishery management goals appropriate to the stock condition. In addition, because vertical behavior is strongly tied to thermocline depth, the latter could potentially be used to adaptively manage driftnet set depths to influence shark catches. 
Acknowledgments California Sea Grant (Grant \# R/F-193) provided research funding and traineeship support for D. Cartamil, C. Sepulveda, and N. Wegner. D. Cartamil was also supported by a fellowship from the Alliance for Graduate Education and the Professoriate, and the Tuna Industry Endowment Fund. Additional funding was received by the William $\mathrm{H}$. and Mattie Wattis Harris Foundation, the Tinker Foundation, the Moore Family Foundation, UC Mexus-CONACYT, the CA Ocean Protection Council, and the Save Our Seas Foundation. We thank J. Steinitz and the SIO Development Office for help in obtaining private funding and the Southwest Fishery Science Center for use of the R/V 'Phoenix'. Thanks to C. Lennert for statistical advice, J. Blum for Matlab assistance, and E. Kisfaludy, J. Schram and J. Gaeta for help with field operations. All procedures were performed under the guidelines of the Institutional Animal Care and Use Committee of the University of California, San Diego (protocol S00080).

Open Access This article is distributed under the terms of the Creative Commons Attribution Noncommercial License which permits any noncommercial use, distribution, and reproduction in any medium, provided the original author(s) and source are credited.

\section{References}

Aalbers SA, Bernal D, Sepulveda CA (2010) The functional role of the caudal fin in the feeding ecology of the common thresher shark (Alopias vulpinus). J Fish Biol 76:1863-1868

Allen LG, DeMartini EE (1983) Temporal and spatial patterns of nearshore distribution and abundance of the pelagic fishes off San Onofre-Oceanside, California. Fish Bull 81:569-586

Altringham JD, Block BA (1997) Why do tuna maintain elevated slow muscle temperatures? Power output of muscle isolated from endothermic and ectothermic fish. J Exp Biol 200:2617-2627

Baquero A (2006) Horizontal and vertical movements of the common thresher shark (Alopias vulpinus) in the Southern California Bight. MS thesis, University of San Diego

Bernal D, Sepulveda CA (2005) Evidence for temperature elevation in the aerobic swimming musculature of the common thresher shark, Alopias vulpinus. Copeia 2005:146-151

Blank JM, Morrissette JM, Landeira-Fernandez AM, Blackwell SB, Williams TD, Block BA (2004) In situ cardiac performance of Pacific bluefin tuna hearts in response to acute temperature change. J Exp Biol 207:881-890

Block BA, Dewar H, Williams T, Prince ED, Farwell C, Fudge D (1998) Archival tagging of Atlantic bluefin tuna (Thunnus thynnus thynnus). Mar Technol Soc J 32:37-46

Bone Q, Chubb AD (1983) The retial system of the locomotor muscles in the thresher shark. J Mar Biol Assoc UK 63:239-241

California Department of Fish and Game (2009) Review of selected California fisheries for 2008: coastal pelagic finfish, market squid, ocean salmon, groundfish, California spiny lobster, spot prawn, white seabass, kelp bass, thresher shark, skates and rays, Kellet's whelk, and sea cucumber. Calif Coop Ocean Fish Invest Rep 50:14-42

Carey FG, Robison BH (1981) Daily patterns in the activities of swordfish, Xiphias gladius, observed by acoustic telemetry. Fish Bull 79:277-292

Carey FG, Scharold JV (1990) Movements of blue sharks Prionace glauca in depth and course. Mar Biol 106:329-342

Carlucci AF, Eppley RW, Beers JR (1986) Introduction to the Southern California Bight. In: Eppley RW (ed) Plankton dynamics of the Southern California Bight. Springer, Berlin $373 \mathrm{pp}$
Cartamil D (2009) Movement patterns, habitat preferences, and fisheries biology of the common thresher shark (Alopias vulpinus) in the Southern California Bight. Ph.D. dissertation, Scripps Institution of Oceanography. $146 \mathrm{pp}$

Cartamil DP, Lowe CG (2004) Diel movement patterns of ocean sunfish Mola mola off southern California. Mar Ecol Prog Ser 266:245-253

Cartamil D, Wegner N, Kacev D, Ben-aderet N, Kohin S, Graham JB (2010a) Movement patterns and nursery habitat of the juvenile thresher shark, Alopias vulpinus, in the Southern California Bight. Mar Ecol Prog Ser 404:249-258

Cartamil D, Wegner NC, Aalbers S, Sepulveda CA, Baquero A, Graham JB (2010b) Diel movement patterns and habitat preferences of the common thresher shark (Alopias vulpinus) in the Southern California Bight. Mar Freshwater Res 61:596-604

Compagno LVJ (2001) Sharks of the world. An annotated and illustrated catalogue of shark species known to date. Volume 2. Bullhead, mackerel and carpet sharks. (Heterodontiformes, Lamniformes and Orectolobiformes). FAO Species Catalogue for Fishery Purposes no. 1, vol. 2. Rome, FAO. 269 pp

Dewar H, Domeier M, Nasby-Lucas N (2004) Insights into young of the year white shark, Carcharodon carcharias, behavior in the Southern California Bight. Environ Biol Fishes 70:133-143

Fritsches KA, Brill RW, Warrant EJ (2005) Warm eyes provide superior vision in swordfishes. Curr Biol 15:55-58

Gubanov P (1972) On the biology of the thresher shark Alopias vulpinus in the northwest Indian Ocean. J Ichthyol 12:591-600

Hanan DA, Holts DB, Coan AL (1993) The California drift gillnet fishery for sharks and swordfish, 1981-1982 through 1990-1991. Fish Bull 175:1-95

Heberer C, Aalbers SA, Bernal D, Kohin S, DiFiore B, Sepulveda CA (2010) Insights into catch-and-release survivorship and stressinduced blood biochemistry of common thresher sharks (Alopias vulpinus) captured in the southern California recreational fishery. Fish Res 106:495-500

Ishida Y, Yano A, Ban M, Ogura M (2001) Vertical movement of a chum salmon Oncorhynchus keta in the western North Pacific Ocean as determined by a depth-recording archival tag. Fish Sci 67:1030-1035

Klimley AP (1993) Highly directional swimming by scalloped hammerhead sharks, Sphyrna lewini, and subsurface irradiance, temperature, bathymetry, and geomagnetic field. Mar Biol $117: 1-22$

Klimley AP, Beavers SC, Curtis TH, Jorgensen SJ (2002) Movements and swimming behaviour of three species of sharks in La Jolla Canyon, California. Environ Biol Fishes 63:117-135

Kohler NE, Turner PA (2001) Shark tagging: a review of conventional methods and studies. Environ Biol Fishes 60:191-223

LaDochy S, Brown J (2003) June gloom and heavy fogs: oceanic influences on bummer California summers. 83rd Annual Meeting of the American Meteorological Society, Long Beach, CA

Nakano H, Matsunaga H, Okamoto H, Okazaki M (2003) Acoustic tracking of bigeye thresher shark Alopias superciliosus in the eastern Pacific Ocean. Mar Ecol Prog Ser 265:255-261

Olvera MAE (2009) Analisis biologico pesquero de la pesqueria con red agallera de deriva en la peninsula de Baja California durante el periodo 1999-2008. MS thesis. Centro de Investigacion Cientifica y de Educacion Superior de Ensenada

MC PF (2003) Fishery management plan and environmental impact statement for U.S. West Coast highly migratory species. Pacific Fishery Management Council, Portland, OR

Preti A, Smith SE, Ramon DA (2001) Feeding habits of the common thresher shark (Alopias vulpinus) sampled from the Californiabased drift gill net fishery, 1998-1999. Calif Coop Ocean Fish Invest Rep 42:145-152 
Preti A, Smith SE, Ramon DA (2004) Diet differences in the thresher shark (Alopias vulpinus) during transition from a warm-water regime to a cool-water regime off California-Oregon, 1998-2000. Calif Coop Ocean Fish Invest Rep 45:118-125

Ressler PH, Holmes JA, Fleischer GW, Thomas RE, Cooke KC (2007) Pacific hake (Merluccius productus) autecology: a timely review. Mar Fish Rev 69:1-24

Schaefer KM, Fuller DW (2002) Movements, behavior, and habitat selection of bigeye tuna (Thunnus obesus) in the eastern equatorial Pacific, ascertained through archival tags. Fish Bull 100:765-788

Schaefer KM, Fuller DW, Block BA (2007) Movements, behavior, and habitat utilization of yellowfin tuna (Thunnus albacares) in the northeastern Pacific Ocean, ascertained through archival tag data. Mar Biol 152:503-525

Sepulveda CA, Kohin S, Chan C, Vetter R, Graham JB (2004) Movement patterns, depth preferences, and stomach temperatures of free-swimming juvenile mako sharks, Isurus oxyrinchus, in the Southern California Bight. Mar Biol 145:191-199

Sepulveda CA, Wegner NC, Bernal D, Graham JB (2005) The red muscle morphology of the thresher sharks (family Alopiidae). J Exp Biol 208:4255-4261
Sepulveda CA, Knight A, Nasby-Lucas N, Domeier ML (2010) Finescale movements of the swordfish (Xiphias gladius) in the Southern California Bight. Fish Oceanog 19:279-289

Smith SE, Aseltine-Nielson D (2001) Thresher shark. In: Leet WS, Dewees CM, Klingbeil R, Larson EJ (eds) California's living marine resources: a status report. University of California, California, pp 339-341

Smith SE, Rasmussen RC, Ramon DA, Cailliet GM (2008) The biology and ecology of thresher sharks (Alopiidae). In: Camhi MD, Pikitch EK, Babcock EA (eds) Sharks of the open ocean: biology, fisheries and conservation. Blackwell Science, Oxford, pp 60-68

Weihs D (1973) Mechanically efficient swimming techniques for fish with negative buoyancy. J Mar Res 31:194-209

Weng KC, O'Sullivan JB, Lowe CG, Winkler CE, Dewar H, Block BA (2007) Movements, behavior and habitat preferences of juvenile white sharks Carcharodon carcharias in the eastern Pacific. Mar Ecol Prog Ser 338:211-224

West GJ, Stevens JD (2001) Archival tagging of school shark, Galeorhinus galeus, in Australia: initial results. Environ Biol Fishes 60:283-298

Wurtsbaugh WA, Neverman D (1988) Post-feeding thermotaxis and daily vertical migration in a larval fish. Nature 333:846-848 